\title{
PEMERKASAAN PELAKSANAAN SULH DALAM KES TUNTUTAN HARTANAH ORANG ISLAM DI MAHKAMAH SYARIAH DI MALAYSIA
}

\section{(Enhancing Sulh Application in Real Estate Property Claims in Malaysian Syariah Courts)}

Wan Azimin Wan Adnan*

wanaziminlawyer72@gmail.com.my

Ahmad Hidayat Buang

ahidayat@um.edu.my

Jabatan Syariah dan Undang-undang, Akademi Pengajian Islam, Universiti Malaya

Terbit dalam talian (published online): 7 Januari 2021

Sila rujuk: Wan Azimin Wan Adnan dan Ahmad Hidayat Buang. (2021). Pemerkasaan Pelaksanaan Sulh dalam Kes Tuntutan Hartanah Orang Islam di Mahkamah Syariah di Malaysia. Kanun: Jurnal Undangundang Malaysia, 33(1), 131-158.

\begin{abstract}
Abstrak
Sulh telah menjadi alternatif kepada proses litigasi sejak tahun 2002 di Malaysia. Dalam kes yang melibatkan tuntutan hartanah, mahkamah syariah menghadapi beberapa cabaran semasa pelaksanaan sulh. Punca utama cabaran ini ialah bidang kuasa yang terhad, di samping isu pentadbiran yang lain. Penulisan ini dilakukan dengan objektif untuk menganalisis kaedah pelaksanaan sulh di mahkamah syariah dari aspek hartanah di mahkamah syariah. Kajian ini juga mengemukakan saranan penambahbaikan bagi pemerkasaan penyelesaian kes secara sulh di mahkamah syariah. Kajian ini merupakan penyelidikan kualitatif, iaitu data dikumpulkan menerusi kajian perpustakaan dan temu bual dengan pihak-pihak yang terlibat secara langsung dengan proses sulh. Data yang dikumpulkan seperti penghakiman kes dan temu bual dianalisis secara deskriptif kandungannya. Kajian ini mendapati
\end{abstract}


cabaran pelaksanaan sulh berpunca daripada isu pentadbiran. Cabaran perundangan dan bidang kuasa yang terhad tidak banyak memberikan kesan terhadap pelaksanaan tersebut. Hal ini dikatakan demikian kerana pihak mahkamah menggunakan budi bicara untuk melaksanakannya secara fleksibel terhadap undang-undang dan peraturan termasuk prosedur sulh yang sedia ada mengikut kesesuaian. Perkara ini banyak bergantung pada komitmen dan kemahiran pegawai sulh terlatih dan berpengetahuan dalam aspek perundangan dan pengendalian kes. Bagi mengelakkan pertembungan antara peraturan dengan amalan yang berasaskan budi bicara, beberapa langkah penambahbaikan perlu dilakukan. Penambahbaikan ini melibatkan semakan dan penyelarasan undang-undang serta peraturan sulh sedia ada. Implikasi daripada kajian ini dapat membantu memantapkan pelaksanaan sulh dalam bidang hartanah di mahkamah syariah, terutamanya melalui penambahbaikan tersebut.

Kata kunci: Sulh, hartanah, mahkamah syariah

\section{Abstract}

Sulh (settlement) has been used in Malaysia as an alternative to the litigation process since 2002. The Syariah courts face several challenges in carrying out sulh. The main cause of this challenge is limited jurisdiction in addition to other administrative issues. The present study was conducted with the objective to analyse the method of application of sulh concerning real estate in the Syariah courts. This study also suggests improvements to improve the application of sulh for case resolution in the Syariah courts. This is a qualitative study, whereby data was collected through library research and interviews with parties directly involved in the sulh process. The data collected, such as case judgments and interviews, was analysed using a descriptive content analysis. This study found that problems concerning the sulh process are the result of administrative issues, while legal challenges and limited jurisdiction do not have much impact on sulh implementation. This is because the courts use their discretion and implement sulh with flexibility in line with laws and regulations, as well as existing sulh procedures where necessary. Much depends on the commitment and skills of sulh officers who are trained and knowledgeable in legal and case management aspects. To avoid a clash between the rules and discretionary practices, some improvement measures are required. These improvements involve the revision and coordination of existing laws and sulh regulations. An implication of this this study is that it can help strengthen the application 
of sulh in matters concerning real estate in the Syariah courts, especially with the said improvements.

Keywords: sulh, real estate, Syariah Courts

\section{PENDAHULUAN}

Sistem kehakiman Islam bertujuan untuk memutuskan pertikaian, perbalahan dan menegakkan keadilan kepada semua pihak tanpa mengira latar belakang mereka. Proses perbicaraan atau litigasi merupakan pendekatan biasa yang harus dilalui dalam sistem kehakiman bagi menyelesaikan kes tuntutan melibatkan harta dalam kalangan orang Islam. Islam turut menggalakkan perundingan secara sulh kerana dapat menjamin keadilan dan menyelesaikan pertikaian secara damai. Pendekatan sulh bukanlah mekanisme baharu, malah telah diamalkan sejak sekian lama dalam sistem kehakiman Islam. ${ }^{1}$

Sulh merupakan mekanisme pengurusan kes yang dipraktikkan secara meluas di mahkamah syariah bagi mempercepat penyelesaian kes secara damai dan efektif. Pelaksanaan sulh di mahkamah syariah tertakluk pada perundangan dan peraturan yang telah ditetapkan supaya dapat dijadikan garis panduan untuk melicinkan perjalanan Majlis Sulh, serta menyediakan skop kerja yang jelas kepada pegawai sulh. Ketika melaksanakan tugas, seseorang pegawai sulh juga tertakluk pada etika yang ditetapkan dan perlu menguasai kemahiran komunikasi dan interpersonal. Selain itu, terdapat kemudahan seperti sistem perisian e-Syariah (modul sulh) yang menyediakan item formaliti dan teknikal bagi keberkesanan pelaksanaan sulh di mahkamah syariah.

Kebanyakan kajian yang telah dibuat sebelum ini bertujuan melihat keberkesanan pelaksanaan sulh di mahkamah syariah, khususnya di Selangor dan Wilayah Persekutuan dalam kes kekeluargaan dan perceraian dengan menggunakan pelbagai pendekatan metode penyelidikan. ${ }^{2}$ Hasil kajian terhadap isu pelaksanaan sulh mampu

1 Syed, K., Rashid. (2004). Alternative dispute resolution in the contexts of Islamic law. The Vindobons Journal of International Conventional Law and Arbitration, 8 (1), 101 102.

2 Wan Azimin Wan Adnan \& Ahmad Hidayat Buang. (2019). Pelaksanaan sulh dalam kes melibatkan tuntutan hartanah orang-orang islam di mahkamah syariah di Malaysia: Tinjauan terhadap kajian lepas. Journal of Shariah Law Research, 4(1), 27-54. 
mengatasi permasalahan konflik pentadbiran hartanah dan bidang kuasa antara mahkamah syariah, mahkamah tinggi sivil dan institusi pentadbiran tanah. Seterusnya, sulh dapat memberikan penyelesaian yang berkesan dalam pentadbiran hartanah orang Islam di Malaysia, serta dapat mempercepat kes tuntutan harta di mahkamah syariah secara damai dan harmoni.

Sehubungan dengan itu, kajian mendalam perlu dijalankan bagi menilai keberkesanan pelaksanaan sulh yang mampu menjadi mekanisme efektif di mahkamah syariah di Malaysia. Isu pelaksanaan sulh di mahkamah syariah menjadi sebahagian daripada subjek kajian. Saranan penambahbaikan dari aspek pengurusan kes sulh, perundangan, prosedur dan sebagainya yang dikemukakan dapat membantu pihak yang berautoriti seperti Jabatan Kehakiman Syariah Malaysia (JKSM) untuk menyelaraskan aspek pelaksanaan sulh dan pengurusan kes yang sistematik di negeri-negeri di Malaysia. Pemerkasaan pelaksanaan sulh yang ditambah baik mampu memberikan perkhidmatan yang berkesan bagi mempercepat penyelesaian kes yang kompleks dan menghindari konflik perundangan dalam bidang kuasa yang wujud antara institusi kehakiman syariah dengan sivil di negara ini.

Penulisan ini membincangkan pelaksanaan sulh di mahkamah syariah sebagai mekanisme yang berkesan bagi penyelesaian kes tuntutan hartanah orang Islam di mahkamah syariah. Perkembangan pelaksanaan sulh yang telah dipraktikkan dalam kes yang telah diputuskan membuktikan bahawa sulh mempunyai prospek yang baik untuk dikembangkan melalui cadangan penambahbaikan yang disarankan. Pemerkasaan sulh di mahkamah syariah mampu membantu mempercepat penyelesaian kes dan menyelesaikan isu pentadbiran hartanah orang Islam di Malaysia.

\section{SULH DALAM SISTEM PENTADBIRAN MAHKAMAH SYARIAH DI MALAYSIA}

Pensyariatan sulh ini dapat difahami berdasarkan hadis yang telah diriwayatkan oleh 'Amru bin 'Awf, bahawa Rasulullah SAW bersabda, yang bermaksud:

"Sulh ialah sesuatu yang harus dalam kalangan Muslim kecuali yang mengharamkan sesuatu perkara yang halal atau yang menghalalkan sesuatu yang haram, dan orang Islam terikat dengan syarat (janji) yang 
dibuat mereka melainkan syarat (janji) untuk mengharamkan yang halal atau menghalalkan yang haram."

(al-Tarmizi)

Hadis ini menjelaskan bahawa proses sulh diharuskan oleh syarak jika menepati syarat-syaratnya. Sekiranya wujud dalam akad sulh unsur yang berlawanan dengan syarak, maka pelaksanaannya ditegah dan sebarang unsur penipuan atau menzalimi antara satu sama lain dielakkan. Oleh sebab umat Islam terikat dengan syarat perjanjian, maka menjadi kewajipan kepada pihak-pihak yang bertikai memastikan perjanjian penyelesaian secara damai itu dipatuhi.

Penyelesaian secara sulh mempunyai pelbagai kelebihan berbanding dengan proses perbicaraan. Mekanisme sulh menjadi alternatif kepada proses litigasi dan dapat menamatkan pertikaian secara damai tanpa melalui proses perbicaraan yang panjang. Pihak-pihak memberikan pandangan mereka dalam Majlis Sulh secara tidak terikat dengan prosedur perbicaraan yang rumit. Selain itu, perundingan sulh mementingkan aspek kerahsiaan. Sebarang maklumat yang tidak sepatutnya terdedah kepada pengetahuan masyarakat umum di dalam dewan yang terbuka dapat dielakkan.

Dalam proses perbicaraan, prosedur seperti keterangan bersumpah (ikrar), kesaksian (syahadah) dan bayinah perlu dilalui. Sebarang keterangan yang tidak jelas dan menepati maksud sesuatu permohonan tanpa sokongan bukti dan saksi berkemungkinan akan ditolak oleh mahkamah. Seperti dalam kes Hawa binti Embong lwn Ahmad bin Muda3, Mahkamah Tinggi Syariah Terengganu telah menolak permohonan kes harta sepencarian kerana kegagalan plaintif membuktikan kesnya pada tahap yakin atau berat sangka (zan al-ghalib) berdasarkan seksyen 72, 73 dan 74 Enakmen Keterangan Mahkamah Syariah Terengganu 2001. Dalam kes yang melibatkan perbicaraan, aspek pembuktian melalui penzahiran dokumen hartanah dan keterangan saksi merupakan satu keperluan bagi mensabitkan sesuatu pendakwaan. Oleh itu, sulh ialah kaedah yang lebih ringkas dan tidak perlu melalui prosedur perbicaraan yang biasanya memakan masa dan kos serta berisiko ditolak kerana kekurangan bukti dan saksi.

3 Hawa binti Embong lwn Ahmad bin Muda [1425H] 17 (2) JH 199. 
Sulh berperanan mencapai keadilan kepada kedua-dua belah pihak yang bertikai. Pelaksanaan sulh dalam Islam bertujuan mencari titik persetujuan bagi menamatkan pertikaian. Terdapat prinsip asas Majlis Sulh yang dititikberatkan seperti kerahsiaan, peluang sama rata untuk bercakap, kesukarelaan untuk menyatakan pendapat tanpa pengaruh pihak lain dan keseluruhan persetujuan yang dicapai perlu menepati hukum syarak dan undang-undang.

Kelancaran perjalanan proses keadilan di mahkamah amat bergantung pada prosedur yang diamalkan. Undang-undang tentang prosedur dan tatacara juga telah diterima pakai dan diamalkan di mahkamah syariah di Malaysia. ${ }^{4}$ Sulh menjadi sebahagian daripada pengurusan kes yang diamalkan dalam pentadbiran mahkamah syariah di Malaysia dan seharusnya dapat diperkasakan ${ }^{5}$ lagi. Agihan kes kepada Majlis Sulh dapat dilaksanakan pada peringkat pendaftaran kes atau dirujuk oleh hakim bicara mengikut permohonan pihak-pihak atau budi bicaranya.

Mengikut peruntukan Seksyen 99, Akta Enakmen Tatacara Mal Mahkamah Syariah (Wilayah-Wilayah Persekutuan) 1998:

Pihak-pihak dalam apa-apa prosiding boleh, pada mana-mana peringkat prosiding itu, mengadakan untuk menyelesaikan pertikaian mereka mengikut apa-apa kaedah yang ditetapkan atau, jika tiada kaedah sedemikian, mengikut hukum syarak.

Oleh hal yang demikian, peruntukan seksyen 99 ini memperlihatkan maksud sulh yang tidak terhad pelaksanaannya di mahkamah tetapi termasuk penyelesaian pertikaian antara pihak-pihak dengan pendekatan yang pelbagai. Konsep sulh yang diperuntukkan dalam seksyen 99 Enakmen Tatacara Mal tersebut agak luas, termasuk pengendalian sesi sulh oleh hakim bicara itu sendiri atau apa-apa perundingan yang telah mencapai persetujuan pihak-pihak, walaupun dikendalikan oleh pihak peguam atau agensi yang diiktiraf oleh mahkamah syariah seperti Jabatan Bantuan Guaman (JBG).

4 Mohd. Naim Mokhtar (2004). Undang-undang prosedur mal/sivil mahkamah syariah dan sivil di Malaysia. Dlm. Zaini Nasohah. et al. (Ed.), Syariah dan undang-undang: satu perbandingan. Kuala Lumpur: Utusan Publications \& Distributors Sdn. Bhd, (hlm. 65-73).

5 Oseni, U. A. (2011). Sharī'ah Court annexed ADR: The need for effective dispute management in waqf, hibah and wasiyyah cases in Malaysia. 14th Annual Conference of the Shariah Legal Officers of Malaysia, 1-17. 
Bagi memahami perbezaan antara Majlis Sulh dan sulh tersebut, maka boleh dirujuk definisi kedua-dua istilah tersebut yang telah diperincikan dalam kaedah 3 Kaedah Tatacara Mal (Sulh) Negeri Sembilan 2016. ${ }^{6}$ Kebanyakan kaedah tatacara mal sulh di negeri-negeri lain tidak memperincikan definisi kedua-dua istilah tersebut. Majlis Sulh didefinisikan sebagai sesi pengantaraan antara pihak-pihak yang dipengerusikan oleh pegawai sulh. Sulh ialah perundingan persetujuan dan penyelesaian kes antara pihak-pihak sama ada di dalam mahkamah atau di luar mahkamah. Tafsiran bagi kedua-dua istilah ini mampu membezakan maksud sulh dan Majlis Sulh dalam peruntukan seksyen 99 Enakmen Tatacara Mal Mahkamah Syariah negeri-negeri.

\section{IMPLIKASI PELAKSANAAN SULH DI MAHKAMAH SYARIAH}

Sulh merupakan satu daripada mekanisme Penyelesaian Pertikaian Alternatif (PPA) yang diguna pakai secara meluas sebagai penyelesaian kes di mahkamah syariah kini. Kelewatan dalam penyelesaian kes mampu diatasi melalui sesi perundingan sulh atau Majlis Sulh. Antara sebab kelewatan penyelesaian kes termasuklah sesi perbicaraan yang perlu melalui proses teknikal yang rumit di mahkamah. Proses perbicaraan di mahkamah melibatkan hakim dan peguam yang menjadi faktor tidak langsung sama ada melancarkan atau melambatkan proses perbicaraan tersebut. Selain faktor tersebut, masalah komunikasi dan aspek kerjasama antara pihak-pihak yang terlibat turut mempengaruhi perjalanan perbicaraan sama ada berjalan lancar atau sebaliknya.

Sulh sebagai perkhidmatan yang diwujudkan di seluruh mahkamah syariah di Malaysia mula diperkenalkan sejak tahun 2001 di Mahkamah Syariah Selangor. Kaedah tatacara mal (sulh) merupakan perundangan yang diwujudkan di bawah peruntukan seksyen Enakmen Tatacara Mal Mahkamah Syariah negeri-negeri dan berperanan sebagai undangundang bertulis bagi tujuan menentukan garis panduan pelaksanaan sulh. Pelaksanaan sulh turut mengguna pakai arahan amalan, pekeliling jabatan dan manual kerja sulh bagi tujuan penyelarasan dan melicinkan pengurusan kes. Kewujudan Manual Kerja Sulh yang memberikan garis panduan secara seragam kepada pegawai sulh di mahkamah syariah di seluruh Malaysia seperti diperuntukkan dalam Kaedah Tatacara 
Mal (Sulh). ${ }^{7}$ Melalui manual kerja sulh ini pegawai sulh mampu mengendalikan sesi sulh daripada permulaan sesi sehingga akhirnya secara sistematik dan beretika. Tujuan diadakan manual kerja sulh adalah untuk menyelaraskan garis panduan sulh di seluruh Malaysia dan menguatkuasakan pelaksanaan sulh seperti yang diperuntukkan dalam Kaedah Tatacara Mal (Sulh).

Penyelesaian secara sulh ialah persetujuan yang dicapai secara pasti dengan pihak-pihak yang menyatakan keputusan mereka masingmasing dengan reda dan disaksikan oleh pegawai sulh yang berautoriti. Perjanjian penyelesaian yang ditandatangani merupakan bukti secara bertulis sebagai akad persetujuan masing-masing. Oleh itu, sulh berfungsi sebagai mekanisme terbaik bagi menamatkan pertikaian secara perundingan damai dan digalakkan dalam sistem kehakiman Islam.

Kelebihan sulh telah terbukti berkesan menyelesaikan pertikaian yang terbit daripada tuntutan hak masing-masing yang boleh menimbulkan konflik berpanjangan antara pihak-pihak sekiranya tempoh masa penyelesaian kes tersebut memakan masa yang panjang melalui proses litigasi. Penjimatan masa melalui perundingan sulh terhasil apabila pihak-pihak tidak perlu mengemukakan bukti dan memberikan keterangan secara teliti sehingga termasuk membawa saksi seperti dalam proses perbicaraan. Maklumat penting dapat diselaraskan melalui perbincangan dalam suasana terkawal tanpa tekanan daripada mana-mana pihak.

Sulh dari sudut pelaksanaan bersifat fleksibel tetapi lebih berfokus untuk penyelesaian tuntutan pihak-pihak yang terlibat. Persoalan yang kurang penting tidak dianggap sebagai isu yang dipertikaikan dan tidak dipanjangkan perbincangannya. Semasa sesi sulh, pihak-pihak lebih tertumpu pada mengenal pasti keperluan dan kepentingan masingmasing dan membuat pilihan cadangan penyelesaian bagi memenuhi keperluan tersebut. Proses ini secara tidak langsung menyedarkan pihak-pihak tersebut dan membolehkan mereka mengetahui kedudukan masing-masing, serta mencari penyelesaian dalam suasana saling hormat-menghormati.

Keputusan yang diperoleh ini juga dapat dipatuhi dan mendapat kerjasama daripada kedua-dua belah pihak yang bersetuju atas perintah

7 Sheikh Ghazali Abdul Rahman. (2006). Penyelesaian kes-kes kekeluargaan Islam melalui manual kerja sulh. Dlm. Manual Undang-Undang Keluarga Islam. Kuala Lumpur: Penerbit IKIM, hlm. 253. 
yang dikeluarkan kerana yang diputuskan adalah daripada kehendak mereka sendiri. Oleh itu kejayaan kes melalui proses sulh ini amat bergantung pada kesediaan dan komitmen pihak-pihak yang bertikai untuk mencapai persetujuan. Proses sulh dapat menjimatkan masa dan perbelanjaan pihak-pihak yang bertikai kerana tidak melalui proses perbicaraan yang formal dan rumit dan dapat mengurangkan kes yang tertangguh di mahkamah. ${ }^{8}$ Kedua-dua belah pihak yang bertikai mampu melaksanakan tanggungjawab selaras dengan keputusan yang mereka sendiri telah tetapkan. Kepuasan terhadap penyelesaian persetujuan bersama yang dicapai mengurangkan kebarangkalian untuk meneruskan pertikaian melalui proses litigasi. ${ }^{9}$

Sulh seharusnya digunakan bagi memberikan jalan keluar kepada halangan yang wujud berkaitan dengan konflik bidang kuasa dan sekatan berbentuk perundangan. Terdapat beberapa isu seperti perundangan, prosedur dan pentadbiran yang boleh dijadikan subjek kajian untuk dianalisis yang dapat diatasi melalui pelaksanaan sulh dalam kes tuntutan hartanah orang Islam. Dalam kes yang rumit seperti pihakpihak yang tiada locus untuk hadir sebagai pihak-pihak yang menuntut dalam sesuatu prosiding di mahkamah syariah, contohnya salah satu pihak berstatus pasangan suami isteri yang belum disahkan perkahwinan mereka atau bukan warganegara yang ada kepentingan, berstatus ahli waris, maka mereka layak dipanggil untuk hadir ke Majlis Sulh bagi memberikan keterangan dan membantu menyelesaikan kes mengikut budi bicara pegawai sulh.

Prinsip res judicata dalam perundangan juga diterima pakai dalam sistem perundangan syariah seperti diperuntukkan dalam seksyen 94 Akta/Enakmen Tatacara Mal berkaitan dengan persetujuan sulh, iaitu:

Jika dengan persetujuan pihak-pihak suatu tindakan telah diselesaikan Mahkamah boleh pada bila-bila masa dengan persetujuan pihak-pihak itu merekodkan hakikat penyelesaian itu dengan terma-termanya, dan rekod penyelesaian itu hendaklah menjadi pembelaan dengan cara Res Judicata dalam tindakan yang pada matannya adalah sama.

8 Raihanah Abdullah (2009). Penangguhan kes di mahkamah syariah: Cabaran dan penyelesaian. Jurnal Syariah, 17 (1), 1-30.

9 Ainul Jariah, M., \& Syahrina, I. (2010). Alternative dispute resolution use and environment disputes in Malaysia. Dlm. Mediation in Malaysia: The law and practice Petaling Jaya: LexisNexis, (hlm. 192-193). 
Peruntukan seksyen 94 Akta/ Enakmen Tatacara Mal telah menjelaskan bahawa apabila mahkamah yang kompeten telah membuat keputusan mengenai sesuatu perkara, kes tidak boleh dibicarakan sekali lagi oleh mana-mana mahkamah dalam kuasa tindakan yang sama selepas itu, sama ada mahkamah syariah mahupun sivil. Maksud dan prinsip res judicata ini turut dijadikan Arahan Amalan No 14 Tahun 2002 yang menyebut apa-apa keputusan kes atau isu yang sama oleh pihak-pihak yang sama yang dikeluarkan terdahulu oleh mahkamah sesebuah negeri hendaklah dihormati oleh semua peringkat mahkamah di negeri lain. Prinsip res judicata diterima pakai dalam sistem kehakiman Islam seperti yang dinyatakan tersebut sebagai asas untuk menegakkan keadilan. Namun begitu, sekiranya wujud dalam keputusan kehakiman yang terdahulu unsur ketidakadilan dan penipuan, maka Islam membenarkan kes berkaitan dibuka semula bagi tujuan menegakkan keadilan. ${ }^{10}$

\section{MEKANISME SULH SEBAGAI PENYELESAIAN ISU PENTADBIRAN TANAH}

Penyelesaian kes tuntutan melibatkan harta orang Islam sentiasa menjadi polemik dalam kalangan ahli perundangan, pentadbir tanah dan akademik. Kewujudan pelbagai bentuk halangan dari aspek perundangan dan pengurusan turut dialami dalam proses penyelesaian kes melibatkan isu kewangan Islam yang memerlukan penyelesaian pertikaian alternatif berbentuk timbang tara dan pengantaraan. ${ }^{11}$ Konflik bidang kuasa antara mahkamah syariah dengan mahkamah sivil dalam kes tuntutan harta orang Islam menjadi pemangkin kepada cadangan penambahbaikan dan pengharmonian. Terdapat juga kajian yang mencadangkan supaya kes melibatkan harta orang Islam seperti hartanah wakaf diselesaikan secara

10 Noor Inayah Yaakub. (1999). Res judicata in the Malaysian syariah court with special reference to the case of $S$ Osman bin S Karim \& Another v. AK Othman Shah bin PG Mohd. Yussof \& Another. Journal of Malaysian and Comparative Law, 26 (2), 250-252.

11 Nur Khalidah Dahlan, Muhamad Helmi Md Said dan Ramalinggam Rajamanickam (2020). Timbang tara dan Pengantaraan: Penyelesaian pertikaian alternatif untuk Permasalahan Kewangan Islam di Malaysia. Kanun: Jurnal Undang-Undang Malaysia, $32(1), 57-58$. 
damai melalui tribunal atau cadangan prosedur yang lebih ringkas. ${ }^{12}$ Dalam konteks isu agihan dan pembahagian pusaka orang Islam pula, kesan terhadap tanah yang terlibat menjadikannya sempit, tidak ekonomis dan menjejaskan pembangunan tanah orang Islam pada masa hadapan. ${ }^{13}$

Beberapa situasi dan cabaran tersebut membuktikan bahawa mahkamah syariah mempunyai bidang kuasa yang terhad dalam pentadbiran hartanah orang Islam. Melalui penghakiman kes tuntutan hartanah orang Islam yang diputuskan seperti dalam kes pertikaian melibatkan tanah wakaf, pengesahan hibah, harta sepencarian dan wasiat, terus mendapat liputan dan ulasan secara ilmiah dalam jurnal penulisan. Mekanisme sulh turut disarankan diperkasakan bagi tujuan memberikan penyelesaian terbaik secara harmoni bagi meraikan dwisistem mahkamah sivil dan mahkamah syariah yang diamalkan di Malaysia serta memenuhi keperluan masyarakat yang ingin mendapatkan perkhidmatan yang efisien dalam urusan pentadbiran hartanah mereka.

Mahkamah syariah boleh menentukan mereka yang berhak terhadap bahagian harta pusaka si mati yang beragama Islam atau bahagian yang kepadanya masing-masing berhak, penentuan waris dan bahagian setiap orang waris yang dikeluarkan dalam Sijil atau perakuan Faraid. Sijil Faraid memperuntukkan bahagian yang akan diterima oleh waris. Pembahagian dibuat mengikut hukum faraid atau pusaka Islam. Walau bagaimanapun, dalam sesetengah keadaan ahli waris boleh membuat persetujuan dan mengemukakan surat persetujuan atau membuat penolakan atau takharruj. Dalam keadaan ini, maka pembahagian akan dibuat mengikut seperti Surat Persetujuan yang dibuat secara akuan berkanun di hadapan Pesuruhjaya Sumpah atau formaliti persetujuan mengikut Peraturan 4A Akta Pembahagian Pusaka Kecil 1955 seperti kaedah muafakat yang turut digalakkan dalam Islam.

Seperti pengiktirafan menerusi borang persetujuan bagi maksud muafakat ahli-ahli waris dalam penyelesaian kes pembahagian pusaka di pejabat pembahagi pusaka Jabatan Ketua Pengarah Tanah dan Galian (JKPTG) atau mahkamah tinggi sivil, maka perjanjian persetujuan yang telah ditandatangani oleh pihak-pihak di hadapan pegawai sulh

12 Zati Ilham Abdul Manaf (2017). Resolution of Waqf Land Disputes: The Relevance of a Waqf Tribunal in Malaysia. Kertas Prosiding, International Conference on Dispute Resolution, Modern Trends in Effective Disputes Resolution, Universiti Islam Antarabangsa Malaysia (UIAM).

13 Ahmad Hidayat Buang (2008). Appreciation of Syariah Principles in Property Management in Contemporary Malaysia Society. Jurnal Syariah, 16 (3), Keluaran khas, 555-566. 
juga perlu diiktiraf pada peringkat mahkamah sivil dan institusi yang terlibat walaupun perjanjian tersebut tidak dikeluarkan daripada perintah penghakiman persetujuan oleh mahkamah. Hal ini dikatakan demikian kerana status perjanjian persetujuan yang ditandatangani adalah berdasarkan fail kes yang telah didaftarkan secara rasmi di mahkamah dan dibuat di hadapan pegawai sulh atau pegawai kehakiman syariah yang bertauliah.

Perjanjian persetujuan yang telah ditandatangani dalam Majlis Sulh oleh pihak-pihak yang bertikai untuk menyelesaikan kes tuntutan mereka dan dikeluarkan perintah penghakiman persetujuan di mahkamah syariah adalah mengikat pihak-pihak dan boleh diendors serta dikuatkuasakan. Berdasarkan Arahan Amalan No. 5 tahun 2006 telah dengan jelas menyatakan status perjanjian persetujuan sulh yang menepati hukum syarak dan direkodkan serta dijadikan perintah persetujuan oleh mahkamah tidak boleh ditarik balik atau dirayu. Namun begitu, sekiranya wujud kekhilafan berlaku dalam aspek prosedur, semakan kehakiman terhadap perintah persetujuan boleh dibuat bagi menegakkan keadilan.

Dalam kes Tauran bin Abdul Hamid lwn Junaida bt Isa, ${ }^{14}$ perjanjian persetujuan telah dicapai untuk memasukkan harta peninggalan dalam perjanjian persetujuan bagi kes tuntutan harta sepencarian yang telah dilaksanakan oleh pihak plaintif dan defendan yang kedua-duanya telah meninggal dunia. Penghakiman persetujuan yang telah dicapai ini menjelaskan bahawa mekanisme sulh berperanan untuk menyelesaikan aspek yang rumit dan persoalan berkaitan dengan bidang kuasa yang boleh mendatangkan konflik dari sudut perundangan sekiranya kes ini dibicarakan. Perintah penghakiman persetujuan ini mengikat pihakpihak dan perintah mahkamah syariah ini perlu dilaksanakan oleh pihak pentadbir tanah yang berkaitan selaras dengan peruntukan undangundang. Dalam kes ini, hakim bicara telah menilai syarat-syarat yang memenuhi kesahihan sulh sebagai penyelesaian kes. Berdasarkan persetujuan pihak defenden terhadap semua tuntutan plaintif, beliau berpandangan bahawa syarat-syarat sulh tersebut telah dipenuhi dan perintah penghakiman persetujuan dikeluarkan.

Oleh sebab prinsip asas sulh merupakan akad dan persetujuan bersama bagi penyelesaian tuntutan kes, maka perjanjian yang ditandatangani dalam Majlis Sulh ialah dokumen secara bertulis berkaitan dengan pensabitan status hartanah yang dimaksudkan dan tanggungjawab pihak-

14 Tauran bin Abdul Hamid lwn Junaida bt Isa [2012] 1 SHLR 76. 
pihak yang terikat. Penelitian atas asas hukum syarak, fakta, dan undangundang bagi tujuan pensabitan sekali gus mampu untuk menyelesaikan kes hartanah yang menyentuh pelbagai isu dan permasalahan yang rumit. Antara permasalahan yang berkaitan termasuklah undangundang Kanun Tanah Negara 1965, hartanah yang kompleks, sekatan pemilikan mengikut undang-undang dan sebagainya. Melalui kes sulh yang telah diputuskan membuktikan bahawa sulh telahpun berperanan sebagai mekanisme yang berupaya mengatasi permasalahan dan sekatan tersebut. Senarai sekatan tersebut telah dinyatakan dalam seksyen 4(2), Kanun Tanah Negara dan statut-statut yang berkaitan.

Berdasarkan peruntukan Akta Tanah (Kawasan Penempatan Berkelompok) 1960 tersebut, pembahagian terhadap kes yang melibatkan pusaka atau harta sepencarian perlulah dilaksanakan mengikut syarat pemilikan tanah berkenaan. Sekatan pemilikan atau pembahagian ini merupakan isu perundangan yang menjadi antara aspek yang perlu diambil perhatian dalam penyediaan perjanjian penyelesaian dalam Majlis Sulh. Apabila berlaku kematian seorang peneroka pada masa tanahnya masih di bawah Daftar Pegangan Desa, maka pembahagian tanah Felda tertakluk pada Akta Tanah (Kawasan Penempatan Berkelompok) 1960. Seksyen 16 Akta tersebut mengehendaki supaya tanah pegangan desa (rural holding) itu diturun milik kepada seorang waris yang berhak sahaja. Jika lebih daripada seorang yang berhak dan mereka tidak bersetuju secara muafakat melantik seorang sahaja daripada mereka, pentadbir tanah boleh menjual pegangan itu dan hasil jualannya dibahagikan dalam kalangan orang-orang yang berhak mengikut faraid.

Dalam usaha membantu pihak pengurusan Felda menyelesaikan pertikaian melibatkan hartanah Felda, mekanisme sulh mampu berperanan menyelesaikan kes tuntutan harta sepencarian. Dalam kes Maliha binti Monthai lwn Abdul Halim bin Abdul Rahman dan 4 Yang Lain, ${ }^{15}$ plaintif sebagai isteri kepada si mati dan defendan ialah anak-anak arwah si mati seramai lima orang. Dalam kes ini persetujuan dicapai dalam Majlis Sulh antara plaintif dan defendan untuk menyerahkan keseluruhan hartanah Felda yang terlibat kepada plaintif secara keseluruhan sebagai harta sepencarian. Hartanah yang tersebut ialah sebuah rumah dan tapak rumah, sebidang tanah ladang seluas tiga ekar dan sebidang tanah ladang seluas tujuh ekar yang terletak dalam Tanah Rancangan Felda Palong 6, Mukim

15 Maliha binti Monthai lwn Abdul Halim bin Abdul Rahman dan 4 Yang Lain, No. 05200-017-0285-2018 (Tidak dilaporkan). 
Rompin, Daerah Jempul Negeri Sembilan. Walaupun dalam perjanjian ini tidak disebut istilah melepaskan hak tetapi secara tidak langsung menjelaskan unsur keredaan pihak defendan dalam akad persetujuan itu untuk mencapai penyelesaian secara damai tanpa menuntut hak mereka dalam bentuk pemilikan hak milik, hasil terbitan atau manfaat daripada hartanah berupa ladang tersebut.

Dalam pentadbiran hartanah orang Islam, Enakmen Rizab Melayu negeri-negeri turut menjadi asas pertimbangan pihak-pihak yang berautoriti. Enakmen ini hanya membolehkan penurunan dan pemindahan hak milik kepada orang Melayu sahaja. Dengan ini, perintah dan pemindahan milik tanah yang berstatus simpanan Melayu ini tidak dapat dilaksanakan sepenuhnya jika pihak yang menerima milik tersebut tidak tergolong sebagai Melayu, walaupun beliau seorang yang layak menurut hukum syarak.

Selain itu, terdapat juga sekatan pemilikan terhadap selain daripada anak negeri yang telah diperuntukkan dalam statut. Berdasarkan kepada Seksyen 3, Enakmen Tanah Rizab Melayu Kelantan 1930 dan seksyen 2(e), Enakmen Tanah Kelantan 1938 menggunakan istilah "native of Kelantan" termasuk mana-mana orang daripada apa-apa bangsa yang telah lahir di Kelantan dan bapanya juga dilahirkan di Kelantan tanpa mengira apa-apa bangsa. Oleh itu, sebarang urusan pindah milik tanah negeri Kelantan daripada seorang Melayu anak jati Kelantan kepada selain "native of Kelantan" adalah tidak sah kerana mereka tidak termasuk dalam tafsiran Melayu dan anak Kelantan. Dalam kes sebegini, sulh mampu untuk menjadi platform bagi pihak-pihak tersebut mendapat tukar ganti berbentuk wang bagi mendapatkan hak mereka yang disekat dari sudut perundangan untuk memiliki hartanah di negeri-negeri terbabit. Konsep tukar ganti (muawadhah) dan melepaskan hak (ibra') atau takharruj bertepatan dengan kehendak syarak dan boleh diguna pakai dalam pelaksanaan sulh mengikut undang-undang statutori.

Dalam kes pertikaian melibatkan hartanah wakaf kes Majlis Agama Islam dan Adat Melayu Terengganu lwn Tis 'Ata 'Ashar Sdn. Bhd., ${ }^{16}$ hakim syarii telah menerima persetujuan penyelesaian secara sulh antara pihak-pihak. Dalam kes ini, pihak defendan telah bersetuju dengan semua tuntutan pihak plaintif termasuk hartanah tersebut tidak boleh dipindah milik oleh pihak defendan kepada mana-mana pihak ketiga. Keputusan kes ini telah membuktikan bahawa dalam kes yang melibatkan harta wakaf, 
mekanisme sulh boleh berperanan untuk mencari penyelesaian terbaik tanpa melibatkan proses perbicaraan yang panjang di mahkamah sivil.

\section{AGENDA PEMERKASAAN PELAKSANAAN SULH DALAM KES HARTANAH DI MAHKAMAH SYARIAH}

Perkhidmatan sulh yang berada di bawah struktur dan pentadbiran mahkamah syariah adalah berdasarkan peruntukan undang-undang statutori dan peraturan-peraturan khusus seperti Enakmen Tatacara Mal Mahkamah Syariah, Kaedah-Kaedah Tatacara Mal (Sulh), Arahan-Arahan Amalan, Manual Kerja Sulh dan Kod Etika Pegawai Sulh. ${ }^{17}$ Kedudukan sulh yang berpunca kuasa daripada perundangan menjadikan sulh proses terbaik bagi penyelesaian kes tuntutan hartanah orang Islam yang kompleks. Perundangan yang menjelaskan skop bidang kuasa dan tanggungjawab pegawai sulh membantu melicinkan lagi perjalanan Majlis Sulh dan mendatangkan kesan positif kepada masyarakat dan negara.

Satu kajian keberkesanan Majlis Sulh di mahkamah syariah seluruh Malaysia telah dilaksanakan oleh Bahagian Dasar dan Penyelidikan JKSM pada tahun 2010. Kajian ini dijalankan untuk menilai keberkesanan Majlis Sulh yang dilaksanakan di mahkamah syariah di Malaysia setelah hampir 10 tahun pelaksanaannya dalam usaha membantu mahkamah mempercepat penyelesaian kes. Objektif kajian ini adalah untuk mengkaji prosedur Majlis Sulh, kompetensi pegawai sulh, kemudahan fasiliti Majlis Sulh dan mencadangkan langkah penambahbaikan proses sulh dan peningkatan keberkesanannya pada masa hadapan. Kajian yang menggunakan metode kualitatif dan kuantitatif ini mendapati bahawa Majlis Sulh telah berperanan secara efektif melalui komitmen dan ilmu kemahiran yang telah dimiliki oleh pegawai sulh bagi membantu mahkamah syariah menyelesaikan kes secara cepat dan berkesan.

Modifikasi terhadap pelaksanaan sulh menerusi pendekatan bagi mencapai kemaslahatan dan meraikan konsep siasah syariyyah yang bersesuaian dengan perkembangan zaman menjadi objektif dan tujuan utama bagi memperkasakan $\operatorname{sulh}^{18}$ untuk perancangan strategik jangka masa panjang. Tanpa meninggalkan prinsip dan elemen asas sulh yang berteraskan

17 Raihanah Azahari (2008). Sulh dalam kes kekeluargaan Islam. Kuala Lumpur: Penerbit Universiti Malaya, 142-145.

18 Said Bouheraoua (2010). Foundation of mediation in Islamic law and its contemporary application. Dlm. Mediation in Malaysia: The law and practice (hlm. 385-396). Petaling Jaya: LexisNexis. 
fiqah Islam, sebarang penambahbaikan boleh terus diusahakan dengan memasukkan pendekatan semasa termasuk kaedah komunikasi dan ilmu kaunseling terkini bagi meletakkan sulh sebagai mekanisme penyelesaian pertikaian terbaik di mahkamah syariah seluruh Malaysia.

\section{(1) Peningkatan Kompetensi Pegawai Sulh}

Peranan pegawai sulh penting untuk memastikan Majlis Sulh berjalan dengan lancar. Kemahiran komunikasi dan kaunseling yang telah dilalui dalam kursus latihan yang disusun oleh pihak JKSM dan negeri-negeri telah memberikan nilai tambah kepada keupayaan pegawai sulh dalam pengendalian Majlis Sulh yang berkesan.

Pelaksanaan sulh perlu dikendalikan dengan profesional dan penuh bertanggungjawab. Kemahiran dan kepakaran dalam pengendalian majlis perlu dipertingkatkan dengan ilmu kemahiran komunikasi, pengurusan konflik dan pemahaman undang-undang. Kursus lanjutan yang bertaraf profesional juga perlu diperluas kepada pegawai syariah untuk kelayakan dan berkemahiran profesional. ${ }^{19}$ Berdasarkan pemerhatian pengkaji, rata-rata pegawai syariah telah mengikuti kursus asas mediasi di bawah kendalian pihak yang telah ditauliahkan oleh badan profesional yang diiktiraf oleh pihak antarabangsa.

Kursus dan seminar secara teori dan praktikal khususnya kepada pegawai sulh yang baharu mampu menjadikan profesion pegawai sulh ditingkatkan sebagai pegawai berstatus profesional dan terlatih untuk memberikan perkhidmatan yang efisien. Sehubungan dengan itu, siri pembentangan kerta kerja dan pendedahan tentang kemahiran pengendalian sulh dan perundangan semasa oleh pegawai yang berpengalaman perlu diadakan secara berkala.

(2) Mempertingkatkan Taraf Jawatan dan Struktur Organisasi Sulh Mahkamah Syariah

Status pegawai sulh hendaklah dinaik taraf gred perjawatan yang bersesuaian dengan status pegawai kehakiman syariah. Peranan pegawai sulh yang terlibat secara langsung dalam pengurusan kes mahkamah dan

19 Norman Zakiyy, Chow Jen-Tchiang. (2010). Court-Annexed mediation in resolving disputes relating to family in Malaysia, What we need to know before we go forwarding, Malaysian Journal of Syariah and Law, 2, 145. 
terikat dengan kod etika yang sama dengan taraf hakim syarii seharusnya dipertingkatkan kedudukannya dan diberikan kedudukan tersendiri dalam struktur organisasi Jabatan Kehakiman Syariah Malaysia dan negerinegeri.

Pentauliahan pegawai sulh sebagai hakim merupakan suatu perkembangan yang baik. Sesetengah mahkamah syariah negeri telah memberikan tauliah sebagai hakim syarii kepada pegawai sulh. Pegawai sulh terbabit turut dibebankan dengan tugas pengurusan kes, mendengar sebutan kes kali pertama, mengambil keterangan bagi kes permohonan sijil faraid, pengesahan nikah luar negara dan membuat keputusan. Bebanan tugas yang dipikul oleh seorang pegawai sulh di samping tugas hakikinya turut memberikan kesan terhadap pengendalian Majlis Sulh yang dikendalikannya. Pegawai sulh turut berperanan sebagai hakim bicara ketika ketiadaan hakim. Peruntukan masa yang cukup untuk mendengar keterangan pihak-pihak dan merangka penyelesaian terhadap masalah yang berbangkit daripada Majlis Sulh menjadi faktor penting bagi menjayakan Majlis Sulh tersebut. Berdasarkan kajian yang dijalankan oleh penulis, enam kes bagi satu hari merupakan jumlah kes maksimum yang biasanya dihadapi oleh pegawai sulh yang memikul tugas hakikinya sebagai pegawai sulh sepenuh masa.

Berdasarkan statistik kes sulh pada tahun 2018 yang dikeluarkan oleh JKSM menunjukkan bahawa sulh telah berjaya menyelesaikan sebanyak 5292 kes atau $42.9 \%$ daripada 12379 keseluruhan kes sulh yang didaftarkan di seluruh Malaysia. ${ }^{20}$ Kejayaan kes sulh ini merupakan hasil usaha 77 orang pegawai sulh yang direkodkan sehingga kini yang mengendalikan kes-kes sulh di 114 buah dewan bicara di mahkamah syariah di seluruh negara. ${ }^{21}$ Peningkatan kes yang didaftarkan di seluruh negara seharusnya turut melibatkan peningkatan bilangan pegawai sulh dan kakitangan sokongan yang berkaitan bagi mencapai keberkesanan pelaksanaan sulh.

Berdasarkan perkembangan terkini, wujud cadangan dan usaha yang dilakukan oleh pihak JKSM untuk menaik taraf seksyen sulh kepada Bahagian Penyelesaian Pertikaian Alternatif (PPA) bagi meluaskan peranan sulh dan memperbesar struktur pengurusan sedia ada. Pendekatan penyelesaian secara hakam turut dimasukkan di bawah tanggungjawab

20 Mohd. Naim Haji Mukhtar (2019). Konsep rahmah dalam perundangan dan kehakiman syariah (p. 32-34). Kuala Lumpur: JAKIM.

21 Temu bual dengan Ketua Penolong Pengarah Seksyen Sulh JKSM, Putrajaya pada 18 Februari 2020. 
seksyen sulh. Usaha untuk menaik taraf seksyen sulh sedia ada kepada seksyen ADR telah mula diwujudkan di Jabatan Kehakiman Syariah Selangor (JAKESS) yang turut menyelaras hal-hal berkaitan dengan pengurusan hakam.

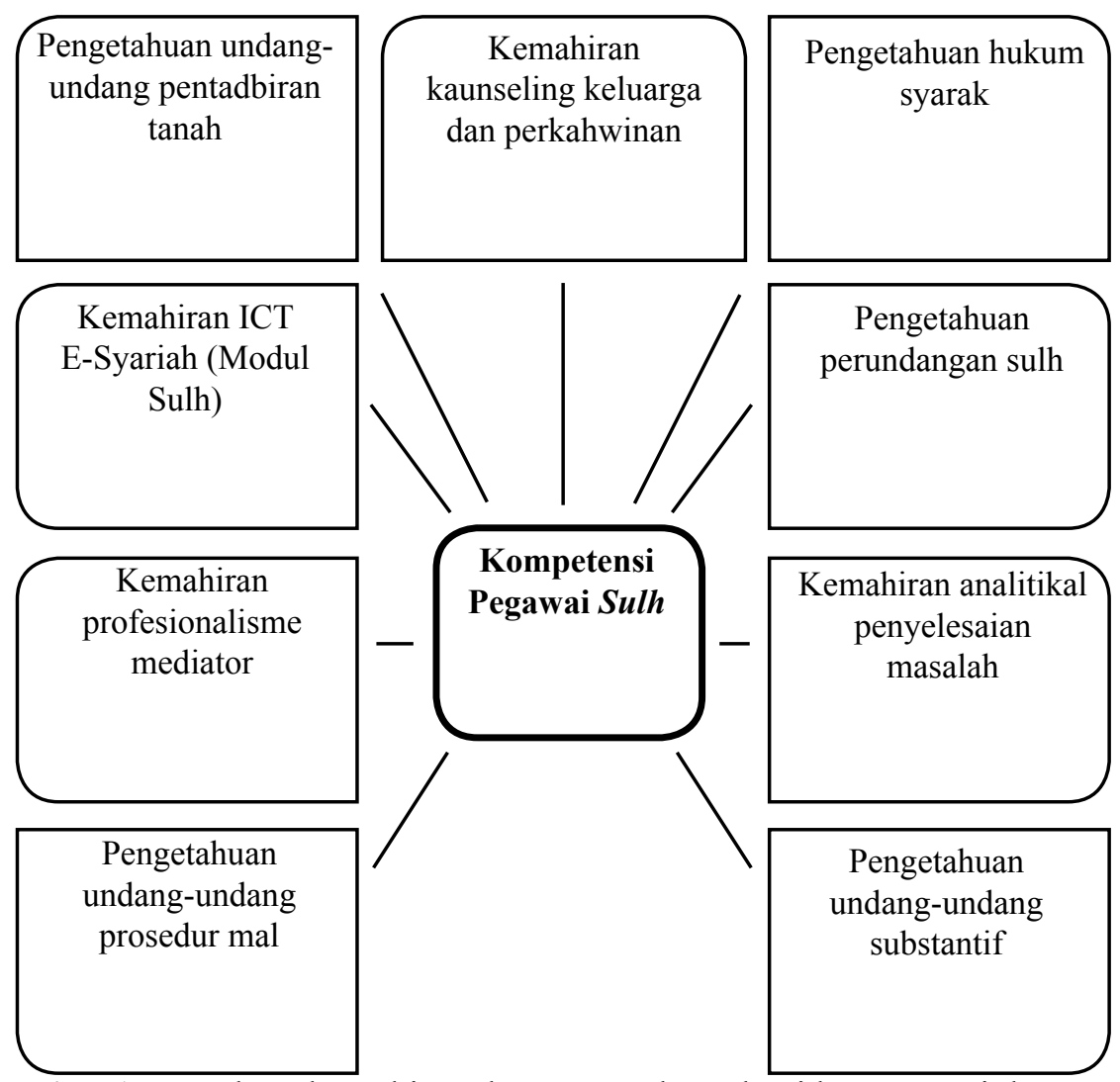

Rajah 1 Keperluan kemahiran dan pengetahuan bagi kompetensi dan profesionalisme pegawai sulh.

(3) Penyelarasan Perundangan dan Pematuhan Arahan Amalan

Proses perjalanan Majlis Sulh telah diberikan garis panduan yang hampir lengkap melalui Kaedah-kaedah Tatacara Mal (Sulh), arahan amalan dan Manual Kerja Sulh. Selain itu, kod etika pegawai sulh pula berperanan 
untuk menjelaskan perkara-perkara yang boleh dilaksanakan dan had tindakan yang tidak boleh dibuat. Namun begitu, dari sudut perundangan yang dirujuk yang dijadikan punca kuasa pelaksanaan sulh, KaedahKaedah Tatacara Mal (Sulh) mahkamah syariah diguna pakai secara berbeza kandungan kaedahnya ${ }^{22}$ di negeri-negeri. Penyeragaman dan penambahbaikan kaedah tatacara mal (sulh) mahkamah syariah perlu dibuat bagi memperkemas perjalanan Majlis Sulh di mahkamah syariah di seluruh negara. Penambahbaikan perlu dilakukan dengan memasukkan kaedah yang lebih berkesan.

Penggubalan kaedah yang terkini seperti di Terengganu pada tahun 2014 dan Negeri Sembilan pada tahun 2016 telah membuat penambahan kaedah yang lebih terperinci berkaitan dengan tatacara sulh. Selain itu, borang-borang khusus juga disediakan bagi melicinkan perjalanan Majlis Sulh. Penyeragaman kaedah tatacara mal (sulh) perlu diselaraskan antara negeri-negeri bagi disesuaikan dengan perkembangan dan pelaksanaan sulh yang terkini.

Berdasarkan analisis kandungan terhadap kaedah yang digubal mendapati bahawa Kaedah Tatacara Mal (Sulh) Negeri Sembilan 2016 mengemukakan pembaharuan dari sudut tempoh sesuatu kes dapat dikendalikan pada peringkat sulh. Berdasarkan tujuh kaedah tersebut dinyatakan bahawa tempoh kes yang dikendalikan oleh Majlis Sulh ialah 60 hari dari tarikh pendaftaran kes. Tempoh masa tersebut berbeza dengan kebanyakan negeri lain yang menetapkan tempoh sulh selama 90 hari. Namun begitu, kaedah berkaitan dengan tempoh masa ini masih tertakluk pada kelulusan untuk pelanjutan masa jika Majlis Sulh tersebut masih memerlukan tangguhan masa untuk penyelesaian.

Kaedah sulh negeri-negeri ini telah memperuntukkan perjalanan Majlis Sulh dan proses tindakan susulan bagi kes yang mencapai persetujuan

22 Kaedah-Kaedah Tatacara Mal (Sulh) 2001 Selangor, Kaedah-Kaedah Tatacara Mal (Sulh) 2004 Wilayah Persekutuan, Kaedah-Kaedah Tatacara Mal Mahkamah Syariah (Sulh) 2004 Johor, Kaedah-Kaedah Tatacara Mal Mahkamah Syariah Sulh (2004) Melaka, Kaedah-Kaedah Tatacara Mal (Sulh) 2007 Kelantan, Kaedah-Kaedah Tatacara Mal Mahkamah Syariah (Sulh) 2005 Pahang, Kaedah-Kaedah Tatacara Mal Mahkamah Syariah (Sulh)(Negeri Pulau Pinang)2019, Kaedah-Kaedah Tatacara Mal Mahkamah Syariah (Sulh) 2010 Sabah, Kaedah-Kaedah Tatacara Mal Mahkamah Syariah (Sulh) Negeri Sembilan 2016, Kaedah-Kaedah Tatacara Mal (Sulh) (Terengganu) 2014, Kaedah-Kaedah Tatacara Mal Mahkamah Syariah (Sulh) (Perlis) 2018, Kaedah-Kaedah Tatacara Mal Mahkamah Syariah (Sulh)(Perak) 2016,Kaedah-Kaedah Tatacara Mal Mahkamah Syariah (Sulh) (Kedah Darul Aman) 2017, Kaedah-Kaedah Tatacara Mal (Sulh) Mahkamah Syariah Sarawak 2012. 
atau menemui kegagalan. Penambahan beberapa kaedah dalam kaedah tatacara mal sulh Negeri Sembilan dan Terengganu mengemukakan suatu pembaharuan kepada kaedah sulh yang sedia ada. Antaranya termasuklah jaminan perlindungan pegawai sulh dijadikan salah satu kaedah bagi memberikan penegasan bertulis bahawa pegawai sulh tidak boleh dipanggil dalam mana-mana prosiding mahkamah berkenaan dengan sesuatu perkara dalam kes yang telah melalui proses sulh.

Arahan amalan ialah surat pekeliling yang tiada kuasa undang-undang seperti statut dan undang-undang tetapi merupakan arahan yang perlu dipatuhi selagi tidak bertentangan dengan mana-mana peruntukan undangundang. Arahan amalan ialah garis panduan atau arahan pentadbiran dalam urusan keseragaman, penggunaan budi bicara hakim-hakim dan pegawai undang-undang atau untuk kelancaran urusan pengendalian kes pada mana-mana peringkat mahkamah.

Kebanyakan arahan amalan yang diguna pakai dan dikuatkuasakan oleh seluruh mahkamah syariah di Malaysia dikeluarkan dan diselaraskan oleh Jabatan Kehakiman Syariah Malaysia (JKSM). Namun begitu, bagi tujuan dikuatkuasakan di mahkamah syariah negeri-negeri, Ketua Hakim Syarii di negeri-negeri perlu mengesahkannya terlebih dahulu untuk memastikannya berkuat kuasa dan diterima pakai pada peringkat negeri. Bermula tahun 2002 hingga tahun 2015 terdapat 13 arahan amalan yang telah dikeluarkan oleh JKSM berkaitan dengan pelaksanaan sulh yang menjadi panduan berkesan dan seragam di seluruh mahkamah syariah di Malaysia. Walaupun demikian, mahkamah syariah negeri sendiri boleh membuat arahan amalannya untuk diguna pakai di negeri masing-masing.

\section{(4) Mewujudkan Jawatankuasa Pemikir Sulh JKSM}

Kewujudan satu jawatankuasa pemikir berkaitan dengan sulh merupakan tindakan yang proaktif bagi menggalakkan sebarang percambahan idea dan mempercepat usaha ke arah penambahbaikan perkhidmatan sulh di mahkamah syariah di seluruh negara. Pelantikan pemikir sulh yang terdiri daripada pegawai sulh yang telah mempunyai pengalaman yang lama dapat digarap idea mereka bagi melahirkan inovasi ke arah memperkemas pelaksanaan sulh secara teori dan praktikal.

Pengalaman yang dimiliki oleh pemikir sulh amat berguna bagi memberikan cadangan penambahbaikan dan maklum balas terhadap sebarang struktur sulh di mahkamah syariah dan program yang dicadangkan oleh pihak JKSM. Pemikir sulh berperanan sebagai pihak yang menyemak 
dan memberikan pandangan dalam aspek perundangan dan kompetensi pegawai sulh. Sebarang modifikasi ke arah keberkesanan sulh dibuat dalam mesyuarat jawatankuasa pemikir sulh untuk mempercepat proses penambahbaikan sulh pada masa hadapan. Antara peranan penting mesyuarat jawatankuasa pemikir sulh yang diwujudkan oleh JKSM termasuklah menyediakan forum perbincangan yang bersifat teknikal bagi mengemukakan cadangan penambahbaikan dan penyeragaman kaedah tatacara mal (sulh) yang diguna pakai di negeri-negeri. ${ }^{23}$

(5) Penambahbaikan Sistem E-Syariah (Modul Sulh) dan Kemudahan Infrastruktur Sulh

Pelaksanaan projek E-Syariah telah bermula sejak Mac 2002 dan dilancarkan secara rasmi pada 7 Februari 2003. Pada tahun 2007, penambahbaikan telah dibuat secara berperingkat dan projek E-Syariah versi 2 telah dilancarkan pada 17 April 2009. Sistem E-Syariah versi 2 diguna pakai sehingga sekarang dan mempunyai beberapa subsistem lain merangkumi sistem Pendaftaran Peguam Syarie, Modul Kewangan, Modul Sulh, E-Bicara, E-Nafkah, E-Faraid dan lain-lain. ${ }^{24}$

Sistem berasaskan teknologi maklumat ini menambahkan lagi kecekapan proses perjalanan sulh bermula dengan pendaftaran kes sulh, agihan kes kepada pegawai sulh yang berkaitan, menyediakan draf perjanjian persetujuan dan draf perintah persetujuan serta menjana laporan statistik sulh. Sistem E-Syariah (modul sulh) yang dibangunkan bertujuan untuk menyelaraskan pendaftaran kes dan mengelakkan berlaku pertindihan bebanan tugas kepada pegawai sulh di mahkamah syariah. Pengagihan kes ke Majlis Sulh dibuat melalui sistem pendaftaran kes sulh yang sistematik. Melalui sistem E-Syariah ini juga, pegawai sulh boleh membuat siasatan dan menyemak apa-apa kes yang bersangkutan dengan kes sulh yang diagihkan kepada beliau secara dalam talian. Penggunaan sistem ini dalam pengurusan kes sulh dapat diselia oleh pihak pentadbiran dengan lebih efisien.

23 Temu bual dengan Ketua Penolong Pengarah Seksyen Sulh JKSM pada 18 Februari 2020.

24 Temu bual dengan Pegawai Teknologi Maklumat Jabatan Kehakiman Syariah Negeri Kelantan pada 28 Januari 2020. 
Penambahbaikan sistem ICT E-Syariah membolehkan sesuatu agihan kes kepada pegawai yang berkenaan dapat dibuat menggunakan sistem E-Syariah (Modul) sekiranya dibenarkan oleh hakim bicara. Sistem ICT E-Syariah perlu ditambah baik dari sudut penyediaan formaliti dengan templat yang seragam. Sistem ICT ini dipercayai akan terus ditambah baik dengan memperkenalkan E-Syariah versi 3. Fungsi baharu akan diwujudkan dengan mengambil kira inovasi yang telah dilaksanakan bersama-sama antara Jabatan Kehakiman Syariah dengan mahkamah syariah negeri-negeri.

Penambahbaikan kemudahan infrastruktur bilik perundingan sulh turut memainkan peranan untuk menonjolkan imej profesional pegawai sulh terbabit. Bilik sulh perlu mempunyai kemudahan yang lengkap bagi menjamin ciri-ciri keselamatan dan memberikan perkhidmatan terbaik kepada pelanggan yang melalui proses pelaksanaan sulh di mahkamah syariah. Kajian keberkesanan yang dijalankan oleh Bahagian Dasar dan Penyelidikan JKSM pada tahun 2010, turut mencadangkan penyediaan dan penambahbaikan kemudahan infrastruktur bagi maksud keselesaan dan keselamatan bilik sulh yang digunakan.

(6) Pelaksanaan Sulh sebagai Mekanisme Pengurusan Kes di Mahkamah Syariah

Kedudukan sulh bukan hanya sebagai proses perundangan secara damai bagi mencapai persetujuan bersama antara pihak-pihak tetapi menjadi sebahagian daripada pengurusan kes mahkamah. Pertemuan awal pihakpihak atau salah satu pihak di hadapan pegawai sulh dikira sebagai sebutan kes kali pertama dan perlu diperincikan proses kerja pada setiap peringkat tersebut. Kehadiran pihak-pihak ke Majlis Sulh dapat merealisasikan konsep pengurusan kes mahkamah syariah yang lebih teratur walaupun pihak-pihak tidak dapat mencapai kes sulh yang berstatus selesai-berjaya.

Dalam konteks peranan sulh sebagai pengurusan kes, proses sulh secara langsung bertindak dengan mengemukakan pendekatan yang membantu pihak-pihak untuk melicinkan perbicaraan di mahkamah sekiranya perlu. Dalam kes yang berstatus selesai-gagal, peranan pegawai sulh dikehendaki menyampaikan saman kepada pihak-pihak dan menyediakan afidavit penyampaian saman tersebut. Pihak-pihak khususnya defendan juga perlu diingatkan supaya mengemukakan penyata pembelaan untuk 
dimasukkan dalam fail kes bagi tujuan perbicaraan akan datang. ${ }^{25}$ Bagi tujuan ini semakan terhadap carta alir proses untuk tujuan pengurusan kes ini perlu dibuat selaras dengan usaha menjadikan sulh sebagai mekanisme meringkaskan proses litigasi dan membantu menyelesaikan isu tunggakan kes di mahkamah syariah.

(7) Menyelaras Aspek Penghakiman Persetujuan dan Semakan Kehakiman Kes-kes Sulh

Perintah hakim terhadap perjanjian persetujuan yang telah dicapai dalam Majlis Sulh perlulah dibuat selaras dengan bidang kuasa mahkamah tinggi syariah yang terlibat. Sebarang perintah yang tidak dibuat berdasarkan bidang kuasa mahkamah yang terlibat akan berhadapan dengan risiko keputusan atau perintah itu akan disemak oleh pihak-pihak yang berautoriti seperti pejabat tanah jajahan atau pejabat pengarah tanah dan galian negeri. Bagi kes-kes semakan penghakiman yang dibuat oleh pihak pentadbir tanah kepada mahkamah rayuan syariah, maka satu garis panduan dikemukakan agar tindakan semakan tersebut dibuat selaras dengan perundangan dan tidak menjejaskan pihak-pihak berkepentingan terhadap hartanah yang dipertikaikan. Sebarang penangguhan terhadap proses tukar milik hartanah akibat penangguhan kes terbabit mengundang pelbagai masalah lain kepada pihak-pihak terlibat pada masa hadapan.

Kajian menyeluruh kes-kes semakan kehakiman terhadap penghakiman persetujuan mendapati bahawa wujud kekhilafan hakim bicara yang tidak mengeluarkan perintah dan merekodkan keseluruhan persetujuan yang telah dipersetujui secara bersama oleh pihak-pihak. Dalam kes semakan kehakiman Nik Zunaidi bin Zakaria lwn Murni binti Mansor, ${ }^{26}$ Mahkamah Rayuan Syariah Kelantan telah menerima rayuan Perayu bagi kes semakan penghakiman kes mal No. 03100-099-0201-2013 berkaitan dengan harta dom. Dalam kes yang dibicarakan di Mahkamah Tinggi Syariah Kelantan, hakim bicara hanya mengeluarkan perintah terhadap sesetengah perkara yang dipersetujui oleh pihak-pihak dalam perkara yang bersangkut paut dengan kes harta dom sahaja, tetapi tidak mengeluarkan perintah dalam item-item yang dipersetujui yang lain termasuk pengesahan

25 Temu bual dengan Pegawai Sulh Jabatan Kehakiman Syariah Negeri Terengganu pada 8 April 2018.

26 Kes Mahkamah Rayuan Syarian Kelantan Nik Zunaidi bin Zakaria lwn Murni binti Mansor No. 03000-003-00003-2015 (Tidak dilaporkan). 
harta sepencarian. Keputusan ini menjelaskan bahawa perintah penghakiman persetujuan adalah termasuk keseluruhan terma persetujuan perjanjian sulh yang telah ditandatangani oleh pihak-pihak. Hakim bicara perlu mengeluarkan perintah persetujuan seperti butiran perjanjian yang ditandatangani selagi tidak bercanggah dengan hukum syarak dan undang-undang.

Terdapat juga kes hakim bicara yang mengeluarkan perintah penghakiman atas persetujuan yang dibuat tanpa kehadiran pihak dan tiada wakalah yang disempurnakan. Dalam kes semakan kehakiman Siti Mariam bt. Hj Samat Iwn Marlia bt. Abbas ${ }^{27}$, Mahkamah Rayuan Syariah Wilayah Persekutuan Kuala Lumpur telah membatalkan perintah penghakiman persetujuan yang telah dibuat dalam kes mal 14600-017-0292-2013 atas sebab wakil yang mendakwa mewakili pihak yang menyatakan persetujuan itu tidak memenuhi syarat-syarat wakalah yang sepatutnya mengikut hukum syarak dan undangundang. Dalam kes Mahkamah Tinggi Syariah Wilayah Persekutuan Kuala Lumpur tersebut, Hakim Bicara telah terkhilaf untuk menerima persetujuan atas anggapan bahawa semua defendan telah bersetuju walaupun ada defendan yang tidak hadir.

Dalam sesetengah kes, hakim boleh membuat pensabitan terhadap senarai harta yang pelbagai termasuk harta sepencarian, harta asal atau harta pusaka mengikut perjanjian persetujuan pihak-pihak dalam bidang kuasa mahkamah berkaitan tanpa perlu mendaftarkan kes tuntutan yang berbeza. Kekhilafan sebegini boleh dielakkan sekiranya satu garis panduan yang lengkap dikeluarkan kepada hakim bicara dalam prosedur pengeluaran keputusan atau perintah penghakiman persetujuan.

Semakan kes yang telah diputuskan melalui perintah penghakiman persetujuan perlu diberikan garis panduan yang lengkap bagi memastikan unsur-unsur yang boleh menjejaskan akad sulh yang telah dilaksanakan mengikut hukum syarak. Semakan terhadap kes yang telah diputuskan melalui persetujuan sulh perlulah tidak menyentuh apa-apa merit dan fakta kes yang dikategorikan termasuk dalam kes rayuan. Arahan Amalan No 7 tahun 2014 berkaitan dengan peraturan semakan kes di mahkamah tinggi syariah dan mahkamah rayuan syariah perlu ditambah baik dengan memasukkan peruntukan khusus berkaitan dengan apa-apa semakan terhadap penghakiman persetujuan yang ingin dipinda atau dibatalkan tidaklah boleh menjejaskan akad sulh yang mengikat pihak-pihak mengikut hukum syarak.

27 Kes Mahkamah Rayuan Syariah Wilayah Persekutuan Kuala Lumpur Siti Mariam bt. Hj Samat lwn. Marlia bt. Abbas, No. 14000-003-0048-2013 (Tidak dilaporkan). 
(8) Mempromosikan Perkhidmatan Sulh dan Mendapat Maklum Balas daripada Pelanggan

Oleh sebab sulh ialah penyelesaian yang terbaik dan berkesan bagi mencapai persetujuan antara pihak-pihak yang bertikai, maka galakan dan promosi sulh ini perlu dipergiatkan agar masyarakat menyedari kewujudan seksyen sulh yang berperanan membantu untuk mempercepat penyelesaian kes mereka. Aktiviti promosi seharusnya dipergiatkan melalui media elektronik, media cetak dan media sosial. Pamplet atau brosur penerangan berkaitan dengan sulh dan kepentingannya juga diedarkan bersama-sama dengan notis sulh yang dihantar bagi memberikan kefahaman tentang proses perjalanan sulh tersebut dan menggalakkan pihak-pihak hadir ke mahkamah untuk mendapatkan perkhidmatan sulh.

Usaha mempromosikan sulh perlu dibuat seriringan dengan penyediaan ruang untuk menerima maklum balas pelanggan terhadap perkhidmatan sulh yang telah disediakan. Sebarang cadangan penambahbaikan daripada pelanggan perlu dijadikan maklumat yang berguna bagi perancangan yang akan datang untuk menginstitusikan sulh sebagai mekanisme penyelesaian pertikaian alternatif terbaik kepada masyarakat. Pengalaman pengendalian sesi mediasi yang telah dilaksanakan di mahkamah keluarga di negaranegara lain seperti di Australia dan Singapura seharusnya dikaji bagi melaksanakan sulh dengan lebih baik dan berkesan pada masa akan datang. ${ }^{28}$

\section{KESIMPULAN}

Pelaksanaan sulh yang berkesan di mahkamah syariah mampu mencapai penyelesaian bagi keperluan pihak-pihak yang bertikai tanpa menghadapi birokrasi dan konflik perundangan sedia ada, melalui prosedur pelaksanaan sulh untuk kes-kes khusus seperti yang disenaraikan dalam Arahan Amalan No. 7 Tahun 2010. Dari sudut usaha pemerkasaan sulh dalam kes tuntutan hartanah masyarakat Islam di Malaysia, didapati cabaran yang wujud berpunca daripada isu pentadbiran. Cabaran dari sudut perundangan dan bidang kuasa pula tidak banyak memberikan kesan terhadap proses pelaksanaan tersebut. Hal ini berikutan pihak mahkamah mengamalkan budi bicara dalam pelaksanaannya secara fleksibel terhadap undang-

28 Aida Othman. (2002). Introducing alternative dispute resolution in Malaysia: Prospects and challenges. Malayan Law Journal, 2 (1), ccxxiv. 
undang dan peraturan termasuklah prosedur sulh yang sedia ada mengikut kesesuaian. Bagi mengelakkan berlakunya pertembungan antara peraturan dengan amalan budi bicara tersebut, maka perlunya penambahbaikan dari aspek semakan dan penyelarasan terhadap undang-undang serta peraturan sulh sedia ada.

Dari aspek pentadbiran pula, terdapat beberapa cadangan penambahbaikan yang dikemukakan, antaranya termasuklah meningkatkan kompetensi pegawai sulh, menaik taraf jawatan dan struktur organisasi sulh, menyelaraskan perundangan dan pematuhan arahan amalan, mewujudkan Jawatankuasa Pemikir Sulh, menambah baik sistem E-Syariah (Modul Sulh) serta kemudahan infrastruktur sulh, melaksanakan sulh sebagai mekanisme pengurusan kes di mahkamah syariah, menyelaras aspek penghakiman persetujuan dan semakan kehakiman kes sulh dan mempromosikan perkhidmatan serta mendapatkan maklum balas daripada pelanggan.

\section{RUJUKAN}

Ahmad Hidayat Buang (2008). Appreciation of syariah principles in property management in contemporary Malaysia society. Jurnal Syariah, 16(3), Keluaran khas, 555-566.

Aida Othman (2002). introducing alternative dispute resolution in Malaysia: prospects and challenges. Malayan Law Journal, 2(1), ccxxiv.

Ainul Jariah, M., \& Syahrina, I. (2010). Alternative dispute resolution use and environment disputes in Malaysia. Dlm. Mediation in Malaysia: The Law and Practice (p. 192-193). Petaling Jaya: LexisNexis.

Hawa binti Embong lwn Ahmad bin Muda [1425H] 17 (2) JH 199.

Kaedah Tatacara Mal (Sulh) Negeri Sembilan 2016.

Kaedah-Kaedah Tatacara Mal (Sulh) (Terengganu) 2014.

Kaedah-Kaedah Tatacara Mal (Sulh) 2001 Selangor.

Kaedah-Kaedah Tatacara Mal (Sulh) 2004 Wilayah Persekutuan.

Kaedah-Kaedah Tatacara Mal (Sulh) 2007 Kelantan.

Kaedah-Kaedah Tatacara Mal (Sulh) Mahkamah Syariah Sarawak 2012.

Kaedah-Kaedah Tatacara Mal Mahkamah Syariah (Sulh) (Kedah) 2017.

Kaedah-Kaedah Tatacara Mal Mahkamah Syariah (Sulh) (Negeri Pulau Pinang) 2019.

Kaedah-Kaedah Tatacara Mal Mahkamah Syariah (Sulh) (Perlis) 2018.

Kaedah-Kaedah Tatacara Mal Mahkamah Syariah (Sulh) 2004 Johor.

Kaedah-Kaedah Tatacara Mal Mahkamah Syariah (Sulh) 2005 Pahang.

Kaedah-Kaedah Tatacara Mal Mahkamah Syariah (Sulh) 2010 Sabah. 
Kaedah-Kaedah Tatacara Mal Mahkamah Syariah (Sulh) Negeri Sembilan 2016.

Kaedah-Kaedah Tatacara Mal Mahkamah Syariah (Sulh)(Perak) 2016.

Kaedah-Kaedah Tatacara Mal Mahkamah Syariah Sulh (2004) Melaka.

Majlis Agama Islam dan Adat Melayu Terengganu lwn Tis 'Ata 'Ashar Sdn Bhd [2010] 2 SHLR 181

Maliha binti Monthai lwn Abdul Halim bin Abdul Rahman dan 4 Yang Lain, No. 05200-017-0285-2018 (Tidak dilaporkan).

Mohd. Naim Haji Mukhtar (2019). Konsep rahmah dalam perundangan dan kehakiman syariah. Kuala Lumpur: JAKIM, 32-34.

Mohd. Naim Mokhtar (2004). Undang-undang Prosedur Mal/Sivil Mahkamah Syariah dan Sivil di Malaysia dlm. Zaini Nasohah. et. al. (Ed.), Syariah dan Undang-Undang: Satu Perbandingan (p. 65-73). Kuala Lumpur: Utusan Publications \& Distributors Sdn. Bhd.

Nik Zunaidi bin Zakaria lwn Murni binti Mansor, No. 03000-003-00003-2015 (Tidak dilaporkan).

Noor Inayah Yaakub (1999). Res Judicata in the Malaysian Syariah Court with Special Reference to the Case of S Osman bin S Karim \& Another v. AK Othman Shah bin PG Mohd. Yussof \& Another. Journal of Malaysian and Comparative Law, 26 (2), 250-252.

Norman Zakiyy, Chow Jen-Tchiang. (2010). Court-Annexed mediation in resolving disputes relating to family in Malaysia, what we need to know before we go forwarding. Malaysian Journal of Syariah and Law, 2, 135151.

Nur Khalidah Dahlan, Muhamad Helmi Md Said dan Ramalinggam Rajamanickam (2020). Timbang tara dan pengantaraan: Penyelesaian pertikaian alternatif untuk permasalahan kewangan Islam di Malaysia. Kanun: Jurnal Undang-Undang Malaysia, 32 (1), 57-58.

Oseni, U. A. (2011). Sharī'ah Court Annexed ADR: The Need for Effective Dispute Management in Waqf, Hibah and Wasiyyah Cases in Malaysia. 14th Annual Conference of the Shariah Legal Officers of Malaysia, 1-17.

Raihanah Abdullah (2009). Penangguhan kes di mahkamah syariah: Cabaran dan penyelesaian. Jurnal Syariah, 17 (1), 1-30.

Raihanah Azahari (2008). Sulh dalam Kes Kekeluargaan Islam (p. 142-145). Kuala Lumpur: Penerbit Universiti Malaya.

Said Bouheraoua (2010). Foundation of mediation in Islamic law and its contemporary application. Dlm. Mediation in Malaysia: The Law and Practice (p. 385-396). Petaling Jaya: LexisNexis.

Sheikh Ghazali Abdul Rahman (2006). Penyelesaian kes-kes kekeluargaan islam melalui manual kerja sulh dlm. Manual Undang-Undang Keluarga Islam. Kuala Lumpur: Penerbit IKIM. 253 
Siti Mariam bt. Hj Samat lwn. Marlia bt. Abbas, No. 14000-003-0048-2013 (Tidak dilaporkan).

Syed, K., Rashid (2004). Alternative dispute resolution in the contexts of Islamic law.

The Vindobons Journal of International Conventional Law and Arbitration, 8 (1), 101-102.

Tauran bin Abdul Hamid v Junaida bt Isa [2012] 1 SHLR 76.

Wan Azimin Wan Adnan \& Ahmad Hidayat Buang (2019). Pelaksanaan sulh dalam kes melibatkan tuntutan hartanah orang-orang islam di mahkamah syariah di Malaysia: Tinjauan terhadap kajian lepas. Journal of Shariah Law Research, 4 (1), 27-54.

Zati Ilham Abdul Manaf (2017). Resolution of waqf land disputes: The relevance of a waqf tribunal in Malaysia. Kertas Prosiding, International Conference on Dispute Resolution, Modern Trends in Effective Disputes Resolution, Universiti Islam Antarabangsa Malaysia (UIAM).

Diperoleh (received): 11 Julai 2020

Diterima (accepted): 09 Disember 2020 